\title{
The Changing Ethos of the Enlightenment in Foucault's Discourse on Parrhesia
}

\section{Oram $M^{*}$}

The Academic College of Tel-Aviv-Yaffo, Israel

*Corresponding author: Matan Oram, Political philosophy - School of Government and Society: The Academic College of Tel-Aviv-Yaffo and reseach fellow in the VanLeer inst. Jerusalem, Israel; Email: oramm@mta.ac.il

\section{Conceptual Paper}

Volume 1 Issue 1

Received Date: August 14, 2018

Published Date: September 14, 2018 DOI: $10.23880 /$ phij-16000106

\section{Abstract}

In refracting the concept of 'reason' through the epistemological prism of 'knowledge', Michel Foucault's philosophical discourse on modernity is an important element in the current definition of critical philosophy. Indeed, Foucault's distinctive thought stems from his synthesizing the investigations of the modern formation of knowledge with critical philosophy. In so doing, he provides a heuristic perspective for the examination of the 'problematic of modernity' through an analysis of the historical developmental of the regnant concept of 'knowledge' as it is intertwined with patterns of social constructions and power structures.

This paper presents a critical analysis of Foucault's seminal understanding of the interaction between the modern concept of knowledge (as against that of the Renaissance) and the 'crisis of modernity'. It seeks to shed light on this interaction in the context of the perceived 'crisis of modernity', which Foucault regards as an outcome of the 'totalizing' conception of 'reason' that lies at the root of the so-called 'human sciences'.

The central issue considered herein is whether Foucault's depiction of the historical unfolding of the modern concept of knowledge - from the Renaissance to the Enlightenment - is consistent with his characterization of the modern concept of knowledge. From the critical perspective of Foucault's thesis of the 'crisis of modernity', the question that arises is whether it would be correct to identify Foucault - the critical philosopher and trenchant critic of modernity - with the 'postmodern' deconstruction and rejection of the Enlightenment. In addressing this question I argue that Foucault's critique of modernity is grounded in his concept of knowledge. Specifically, I contend that his exacting review of the genealogy of the modern conception of reason is meant to extricate rationalism from the grips of this putatively abstract concept of reason. Hence, I conclude that it is profoundly misleading to associate Foucault's critical thought with the postmodern project of deconstruction.

Keywords: Reason; Epistemological; Crisis of modernity; Renaissance; Enlightenment 


\section{Critical Premises for the Philosophical Discourse on Modernity}

Dealing with the philosophical-critical discourse on modernity, the social problematizing of knowledge with the stress on scientific knowledge is a key issue. The prefix 'post' as the word itself implies denotes a demarcating line to distinguish an age or trend over a period of time signified by specific characterizations. Concepts like 'post-medieval', 'post-revolutionary' era or the 'post-colonial' world, for example, seem to indicate an end of a historical epoch; just as 'post-metaphysical', 'post-positivism' and 'post-empiricism' in philosophy or 'post-figurative' in art signify a differentiating articulation toward any trend or tendency that may indicate the starting point of something new and different. The prefix 'post' is therefore a signifier and differentiator in relation to something that is objectified as a 'past definer' which is preconditioned by a certain historical-interpretational perspective. At any rate, two things are supposed in these distinctions: a. the defining meaning of the preceded epoch or trend referred to, and $\mathbf{b}$. that it belongs to a certain past which is known to us. This means that the 'present' which we inhabit is something different in comparison to this 'past'. In other words, this is a 'redefinition' of the present through which our consciousness of reality is formed. Moreover, this present may be a point of reference that provides us with clear indications about the nature of these articulations. By 'post-medieval', for example, we have a (more or less) common idea about the middle Ages; the same may be applied to 'post-positivism' because we know what 'positivism' is.

"Enigmatic and troubling,"1 so described by Michel Foucault, 'postmodernity' may be considered as a source to some key questions that have raised a specific kind of philosophical discourse on modernity. Here it would be worth referring to Richard Bernstein ${ }^{2}$ whose words put the vagueness of 'postmodernity' together with that of 'modernity'; the prima facie case at issue is a common problematic which is 'modern-postmodern'. Thus, he also pointed to a paradox that thinkers like Heidegger, Foucault, Derrida - often tagged as 'postmodern' - did not see themselves as such and accordingly did not consider 'postmodernism' to be an idea or a concept in and of itself. With Foucault in particular, as noted previously, 'postmodernity' as a meaningful concept is emphatically

'See Michel Foucault, 1997. "What is Enlightenment?" in The Politics of Truth, Los Angeles: Semioext (e). pp: 105.

${ }^{2}$ See Richard, J. Bernstein, 1992. The New Constellation: The Ethical

Political Horizon of Modernity/Postmodernity, Cambridge: MIT

Press. pp: 13. rejected. ${ }^{3}$ At any rate, Bernstein suggests that the descriptive designation "modern/postmodern Stimmung" may be accepted in Heidegger's meaning of 'state of mind', 'atmosphere', 'temper', namely, a characterization of shifting, an instability bordering on the amorphous. However, in following Foucault's consideration of 'modernity' as an ethos whose anchor and moral horizon is the Enlightenment, this vagueness of postmodernity should not be confused with 'modernity'. Consequently, my point of departure is that 'modernity' in all its forms ${ }^{4}$ an ethos of a profound social significance - is inseparable from the Enlightenment. Moreover, from this point of departure the 'philosophical discourse on modernity' as a critical discourse stands in opposition to the undermining trend of 'deconstruction'. Such a view of the critical discourse distinguishes between 'criticism' and 'negation' which is at the heart of the philosophical discourse on modernity. Two preliminary premises and focal points of discussion elucidate this discourse as critical thought are a. The horizon of the Enlightenment as modernity's 'selfconsciousness' and $\mathbf{b}$. the elucidations of 'modernity' as a 'project' - a socio-political program based on a particular concept of rationalism which is a normative guide to societal rationalization.

\footnotetext{
${ }^{3}$ And see n. 1, above. In his "What is Enlightenment?" Foucault discusses the connection between the Enlightenment and 'modernity'. He also addressed this issue in an interview given in 1984. See Michel Foucault, 1984. "Space, Knowledge and Power”, an interview with Paul Rabinow, trans. by Hubert C, in Simon During (ed.), 1993. The Cultural Studies Reader, London and New York: Routledge. pp: 164-165.

${ }^{4}$ At the heart of the philosophical discourse on modernity and critical philosophy - by problematizing 'rationalism' -modernity is conceived in terms of crisis. The critical discussion of the meaning of 'reason', 'rationality', 'knowledge', 'science' is common ground to various approaches to critical thought in the philosophical discourse on modernity, for example, in the works of Nietzsche, Husserl, Foucault, Horkheimer, Habermas et al. In his general approach to 'multiple modernities' (accordingly 'modernity' is a distinct civilization), S. N. Eisenstadt claims that 'modernity' is a continuous process of formation and a development of multiplicity and of (frequently changing) trends. Specifically dealing with the problematic of the 'program(s) of modernity' (culturally and politically) - its basic premises, tensions and antinomies - he claims that these changing trends contradict each other and clash frequently. That is, although 'modernity' has spread throughout most of the world, it has not produced a single pattern of modern civilization, but modern civilizations which are constantly changing. This is described by Eisenstadt as societies or civilizations, though exhibiting some similar core characteristics, tend to develop different ideological and institutional dynamics. See S. N. Eisenstadt 2003. Comparative Civilizations and Multiple Modernities (a collection of essays by S. N. Eisenstadt - Vol. Two), Leiden: Koninklijke Brill. Pp. 493-533. See also S. N. Eisenstadt, 1999. Paradoxes of Democracy - Fragility, Continuity and Change, London: The Woodrow Wilson Center Press. Pp. 18-50 especially.
} 


\section{Philosophy International Journal}

The meaning attributed to the Enlightenment as modernity's 'self- consciousness' and moral compass transfuses this dimension of critical thought as a built-in element into the philosophical discourse on modernity. This view of the Enlightenment presupposes the rejection of any tendency to articulate modernity along the perceptive lines of any historical period. Hypothetically, if 'our present' is definable as the 'postmodern epoch', then what is the 'modern past'? That is, any attempt to understand 'what is modernity' involves the question, "What is Enlightenment?"

The critical nature of the philosophical discourse on modernity underlies the perception that 'modernity' is not an epoch or a period of history that may be delineated by any definitional rudiments which attribute it to the past. Therefore, this discourse may not evade one main and troubling question: how could modernity be imagined as a 'completed project', 'bygone era', or an obsolete philosophical trend? Moreover, if the Enlightenment is to be acknowledged as modernity's moral 'selfconsciousness', then prior to asking this question we might wonder whether modernity has even begun. And if so, then for whom and when did it begin? In any case, the discussion of these questions involves deliberation on the moral meaning of the Enlightenment along with its specific ties to the formatting processes of the modern social world. To wit, the connecting points and interrelations between 'modern rationalism' (societal rationalization) and 'modernity' as a conscious formative process requires further elucidation.

This affinity between the Enlightenment and modernity (the modern world of the social in particular) forms a specific 'sense of reality' through the consciousness of modernity as an ethos - a way of thinking and feeling within which the individual's selfdetermination, as an autonomous personality is driven from the basic premise about man as a free and (potentially) rational being. This perception of 'modernity' reflects a way of acting, living and behaving, while at issue is the changing dynamism of socio-political structuring, the transformation of discipliner knowledge to (pseudo-scientific) authority and the shift in the sources of authority of moral norms, cultural reconstruction and communal aggregation. This view which envisages modernity as an ethos not only critically formulates the philosophical discourse on modernity but also problematizes it through particular discontents which bring this discourse back to its philosophical sources - the Enlightenment.

\section{The Enlightenment and the Criticism of Modernity}

Commonly acknowledged as the birthplace of the 'modern ethos', the Enlightenment may be mooted as a source of misperceptions surrounding the question, 'What is modernity'? Scientism's tendency of totality and positivism may be attached to the Enlightenment's heritage; equally as 'anti-positivist' trends of critical thought may claim the same affinity. As a common source for various tendencies in a wide range of areas of human knowledge, the Enlightenment - an inclusive term for a certain intellectual spirit and moral sentiment - may be reflected through the 'rational-universality' of natural rights (human and civil rights) on one hand, and the particularism of the 'nation state' on the other. Both the doctrine of 'natural rights' and the concept of the 'nation state', though these may reflect different worlds of moral outlooks, they are generally considered to be part of the broader context of the Enlightenment and the French Revolution. In other words opposing points of view and interpretations of historical events may equally be attached to the same intellectual source. Indicating a common basis for opposing views, this argument may explain the tendency to blur the contradictions between the national ethos and 'political-liberalism', 5 each of which in one way or another is one of the characteristics of modernity. Namely, the contradictions between the conflicting particularity of 'nationalism' as a moral sentiment of a certain community and the rational universality of the premises of natural rights whose actualized embodiment in the socio-political praxis is the modern concept of any constitution founded on human rights and liberties.

This tension between the 'universal' and the 'particular' may historically be recognized since the Jacobin Reign of Terror and the French Revolution as a whole, together with the reactionary anti-Enlightenment and the royalist trends of extreme right movements; to the nineteenth century of national awakening and the twentieth century with all its disasters and upheavals rooted in nationalism. The reflection of this tension is evident in the inner world of nationalist political thought whose particular discourse of 'national liberation' relied on the rational universal premises underpinning human and civil rights. So, in the nationalist ideological discourse one may find 'human liberation' being actualized as part

\footnotetext{
${ }^{5}$ Regarding the universality of the rational premises of 'political liberalism', see John Rawls, 1993. Political Liberalism, New York: Columbia University Press. More specifically, see his 'Reply to Habermas', The Journal of Philosophy XCII, 3 (March 1995).
} 


\section{Philosophy International Journal}

of 'liberating the nation'. However, contradictions and paradoxes may be noticed also in the "Pantheon of Immortals" whereas none other than Voltaire - the prominent philosophe of the Enlightenment who sharply criticized intolerance - comes to the absurd of antiSemitic slander, hate speech and discrimination against the Jews. All this, it should be noted, as against the glorious, valiant discourse on equity, freedom of speech, liberties and human rights as is widely known to emerge from one of the great spokesmen of tolerance and also considered to be one of the greatest philosophers of the Enlightenment. From the perspective of modern political history, 'pathologic paradoxes' may be conceived in those nationalist movements and ideologies ${ }^{6}$ which have fulfilled their vision of national liberation through a nation state that gave rise to a dictatorship of repressive political regimes.

As a divergence of intellectual currents in a variety of dimensions of human knowledge, the Enlightenment may be considered as a driving force of the ethos of modernity. It denotes a profound change in the meaning of the concept of 'knowledge' as a basis for the formation of the 'modern mind'. From the retrospective angle of the developmental history of modernity, this change indicates unprecedented interrelations between 'knowledge' and the world of the social. At issue is a revolutionary change that its occurrence notes the human social significance of science activated by a conception of knowledge that will later be classified under an ordering taxonomy of disciplinary specialized knowledge. Moreover, a changing moral sentiment takes place through rational consciousness. That is, the Enlightenment's concept of knowledge expresses the spirit of liberty by way of human reason.

In a long developmental process by which religion has been pushed aside to the realm of private life, it was the inspiration of the 'scientific method' that formed the rationalism which dominated the modern mind through 'societal rationalization'. The 'society' as an infrastructure of political community is the modern demos which embodies sovereignty through the basic conviction of equal political participation. This manifestation of equality is a foundational principle of a constitutional anchoring of human and civil rights that has taken root as an essential element of the (modern) liberal democratic constitution. Reflecting the 'spirit of the Enlightenment',

${ }^{6}$ See Zeev Sternhell, 1984. "Aux source de l'idéologie fascist: La revolt socialistecontre le materialism", in Totalitarian Democracy and After - International Colloquium in the Memory of Jacob $L$. Talmon (21-24 June), Jerusalem: The Israel Academy of Sciences and Humanities, Magnes Press, The Hebrew University of Jerusalem. these aspects of rights and liberties indicate the essential connection between 'rationalism' and 'modernity'. Assuming the Enlightenment through the activation of human reason ${ }^{7}$ signifies itself as an ethos, the Enlightenment symbolizes the starting point of modernity. What for Mendelssohn is an intellectual cultivation, for Kant the Enlightenment is man's emergence from nonage by daring to use one's own mind without another's guidance. However, exactly here, at this point, a challenging question arises: namely, what is the nature of the relationship between 'rationalism', Enlightenment and 'modernity'? Is it necessary to involve a specific conception of the 'project of modernity'? Assumingly it is. But by itself does it derive any subordination to a certain type of 'societal rationalization' dictated by a specific perception of rationality? Could 'public use of reason' be categorically formulated? In short, these questions regarding the relationship between rationalism, Enlightenment and modernity form the philosophical discourse on modernity as critical thought. Thus, it postulates that this discourse must begin with the interrelations between rationalism and Enlightenment.

\section{Progress and Critical Thought}

Signifying the ethos of modernity, the Enlightenment as the progress of humanity towards the development of liberty (to adopt something of the Hegelian language) is imagined as a rational universalist spirit aimed at achieving human equality and freedom of thought. As such, however, the 'spirit of Enlightenment' symbolizes a horizon of progress through a variety of different perceptions of human knowledge and moralities. The formation of the concept of 'modern science' may be considered as the high point in the long evolutionary development of human knowledge, a process which began with the 'scientific revolution'. In this sense, the Enlightenment echoes the transformation of views of society and nature where, retrospectively, in many aspects the 'scientific method' will be transposed into the world of the social through processes of 'societal rationalization'. As an adjectival formation - 'enlightened personality', 'enlightened liberalism' or 'enlightened state' - this spirit of Enlightenment reflects a certain value

\footnotetext{
${ }^{7}$ For Mendelssohn who was the first to answer the question Was ist Aufklärung?, the Enlightenment is first and foremost an intellectual cultivation (distinguished from the practical) or as Kant later put it (in agreement with Mendelssohn): “Enlightenment is man's release from his self-incurred tutelage. Tutelage is man's inability to make use of his understanding without direction from another [...] Sapere aude! Have courage to use your own reason! - that is the motto of Enlightenment." These translated lines from Kant's Was ist Aufklärung? are extracted from Michel Foucault, 1997. The Politics of Truth, Los Angeles: Semiotext(e). pp: 29.
} 


\section{Philosophy International Journal}

sphere denoting progress driven by a certain moral commitment.

Referring to the historiographical aspect, Daniel Breuer suggests that "...the Enlightenment can be understood, as Jean Marie Goulemont puts it, as 'a series of arbitrary reconstructions possessing their own historicity'." 8 Dealing with 'modernity' through this abstraction of 'Enlightenment' - 'progress' 'rationalization', I would propose a multilayered comprehension of the concept of Enlightenment to be a basis for a critical view of the 'societal rationalization' that mainly forms our imagination of modernity. This critical view is directed through the comprehensive question which may outline the philosophical discourse on modernity. That is, how are 'societal rationalization' and the vision of progress connected? Put differently, in dealing with the ethos of modernity, is there any point in making the Enlightenment (its spirit and heritage) a touchstone of progress against 'societal rationalization'? Then, 'what is progress'? I am assuming that this question is no less critical than asking if there is anything at all like the 'project of Enlightenment'. Wouldn't it be an imagined concept that gives a moral meaning to a certain sociopolitical reality? Perhaps this problematic, given the variety of questions it raises, can be summed up with one question. That is, should Enlightenment be conceived as a horizon of hope, or after all maybe we just view it as an anatomy of despair? ${ }^{9}$ Asking questions instead of making categorical determinations is what may sometimes be the difference between negation and critical thought; that is, between 'deconstruction' and 'reconstruction', and between progress and decline.

In pursuit of an illuminating analysis of the concept of progress, I would propose a point of departure for dealing with these challenging questions. It is the adoption of a different approach for a multi scale concept such as the Enlightenment that should be acknowledged as a variety of ideas which are brought forward on a common foundation, namely, progress. Moreover, as much as these ideas reflect modernity through a 'societal rationalization', then, it may by no means be applied through a one-dimensional, instrumental conception of rationality. That is, the Enlightenment as an ethos in our context of modernity is to be addressed through a specific point of affinity.

${ }^{8}$ Daniel Breuer, 2008. The Enlightenment Past - Reconstructing Eighteenth-Century French Thought, Cambridge: Cambridge University Press. Pp: 12.

${ }^{9} \mathrm{Or}$ as Jürgen Habermas put it, Should we give up on the project of Enlightenment?
Though inspired by the vision of progress, modernity's despair and crisis are widely acknowledged. The interpretation of this view of those 'universal-rational' principles, values and ideas of the Enlightenment have created a consciousness of the 'program of modernity' or maybe better, modernity as a program. The transduction of liberté, égalité, fraternité from the realm of abstract ideas into socio-political praxis has transformed modernity into the representation of the 'project of the Enlightenment'. In this context, the French Revolution is acknowledged as the formative event that generated the uncompromising demand for radical change in the sociopolitical order. It has stimulated a process of sociostructural change that was shaped by advancing a specific interpretation with three dimensions of 'modern consciousness': a. the rational-scientific concept of knowledge, b. liberty through the practices of individual autonomy, and c. the power of discipliner knowledge.

This view of the Enlightenment is intertwined with the developing lines of a differentiated consciousness; what will (later) be demarcated through the discipliner separation of 'humanities' from 'science'. The undisputed victory of the 'scientific method', or the positivist/natural sciences (or, merely, 'science') - and the associated technological advantages in particular -has created an estranging separation between 'science' and the 'humanities', 10 where indeed the latter has been pushed aside as something inferior. Herein, to imagine, the birthplace of a hybrid such as 'human/social science(s)' while the process of decline of the humanities accompanies the dominance of instrumental rationality. Though its research object is man and society, the human/social sciences have developed the tendency of adopting the paradigmatic subjectivity of the study of the phenomenal world of nature (natural sciences).Its configuration as an (experimental) diagnostic discipline of knowledge is supposed to grant it the authoritative positioning of science. Therefore, as Foucault has well expressed it,

...the 'human sciences' are dangerous intermediaries in the space of knowledge. [...] What explains the difficulties of the 'human sciences', their precariousness, their uncertainty as sciences, their dangerous familiarity with philosophy, their ill-defined reliance upon other

\footnotetext{
${ }^{10}$ Isaiah Berlin has specifically discussed this issue in his essay (see below) where he deals with the developmental history of the differences between the natural sciences and the humanities. See Isaiah Berlin, "The Divorce between the Sciences and the Humanities" in Isaiah Berlin, 1955. Against the Current: Essays in the History of Ideas, Princeton and Oxford: Princeton University Press (2001). Pp. 80-110.
} 
domains of knowledge, their perpetually secondary and derived character, and also their claim to universality, is not, as is often stated, the extreme density of their object [...] but rather the complexity of the epistemological configuration in which they find themselves placed [...]. ${ }^{11}$

Both liberal and totalitarian regimes have stripped religion of its control over souls. The ideological discourse of modern total itarianism's oppression is achieved by use of cultural arrays, knowledge and power or powerthrough-knowledge. One of the salient features of 'closed societies' 12 is the monitoring of private life and the curtailment of liberties usually justified by the importance of the need for 'governance', which engenders strengthening the control and the authority of political power. The separation between religion and state - as an essential characteristic of the 'modern state' - is one of the hallmarks of modernity. The exclusion of religion from political power by relocating it to the life world's sphere of particularity is a foundational element of liberties and rights. Hence, as far as the modern world of the social is concerned, 'societal rationalization' is an indispensable element in our understanding of modernity. However, societal rationalization is among other things a pattern of social structuration and political institutionalization. Furthermore, 'rationalization' - by its very nature and as modernity's consciousness formation - is loaded with moral meaning. This, first and foremost is being expressed by questioning the meaning of progress which in many ways can be said to be the morality of Enlightenment.

Insofar as an era may be defined through its distinctive cultural and epistemological presuppositions, then the period from Renaissance to modernity can be viewed as an epoch marked by the rise of modern science. ${ }^{13}$ This paved the way for the crystallization of a

\footnotetext{
${ }^{11}$ Michel Foucault, 1966. The Order of Things - an Archaeology of the Human Sciences, London: Tavistock, 1970. pp: 348.

${ }^{12}$ Here I recall Popper who coined the differentiating terminological concept of 'open society' vs. 'closed society' which is also connected to the meaning of the term 'rationalism': "My way of using the term 'rationalism' may become a little clearer, perhaps, if we distinguish between a true rationalism and a false or pseudo-rationalism. What I shall call the 'true rationalism' is the rationalism of Socrates. It is the awareness of one's limitations, the intellectual modesty of those who know often they err, and how much they depend on others even for this knowledge. It is the realization that we must not expect too much from reason [...] 'pseudo-rationalism' is the intellectual intuitionism of Plato. It is the immodest belief in one's superior intellectual gifts, the claim to be initiated, to know with certainty, and with authority." See Karl R. Popper, 1945. The Open Society and its Enemies (Vol. II), London: Routledge \& Kegan Paul, 1963. pp. 227. ${ }^{13}$ Otherwise, it was called the 'Age of Reason' or L'âge classique.For example, see Michel Foucault, 1972. History of Madness, New York: Routledge, 2006. This unabridged English edition is the translation
}

Oram M. The Changing Ethos of the Enlightenment in Foucault's Discourse on Parrhesia. Philos Int J 2018, 1(1): 000106. new concept of reason that will be identified with a particular conception of 'rationality'. In terms of the human social world, it is the beginnings of a process that determined the social meaning of modernity through 'societal rationalization'. Parallel to the ongoing process of consolidation of the scientific method since the sixteenth century onwards -from Montaigne, Hobbes, Vico or Hume to Husserl, Foucault or Habermas 'rationalism'/'rationality'14has been problematized as a multifaceted concept. However, in retrospect, the prevailing and overarching process was that by which the introspective perception of knowledge had been replaced by the positivist paradigm. This shift affirms social action whose legitimacy is established by the very fact that it is grounded in 'scientific knowledge'. This critical argument can be seen as something of a common denominator between Foucault and Habermas. However, for Foucault this concept of knowledge is the source of 'disciplinary violence', a means leading to oppression, confinement and exclusion; while in Habermas' critical thought it serves as a central factor in a process of social fragmentation resulting from the domination of 'instrumental rationalism', against which he proposes 'rationalcommunicative reconstruction'.

In a social existence of 'open society', ${ }^{15}$ one can discern a 'totality' that is identified with a process in which the concept of reason is reduced to positivist rationalism. ${ }^{16}$ It was the scientism of disciplinary knowledge that produced 'human/social science'. At issue is a onedimensional, instrumental perception that depersonalizes human beings under the 'legitimating' dynamism of (pseudo)science. It is this ambition for validity within which the 'social sciences' accord with a continually reconstructed rationality. As a consequence, its

of Michel Foucault, Histoire de la Follie à l'âge classique, Paris: Gallimard [first published in French as Folie et Déraison: Histoire de la folie à l'âge classique, Paris: Librarie Plon, 1961]. On the developmental process of the relationship between knowledge/scientific knowledge and the structuration of rational consciousness in Foucault's thought, see Michel Foucault, 1966. The Order of Things, London: Tavistock, 1970. Pp. 125-165 specifically.

${ }^{14}$ It is worth noting here that the common denominator of this problematizing is the affinity (with a varying degree of significance) to the question of knowledge/scientific knowledge as a prominent feature in the wider context of the interrelation between 'critical thought and modernity'.

${ }^{15}$ To the extent that 'liberalism' as a socio-political culture and morality, does indeed reflect the socio-political meaning of 'open society'.

${ }^{16}$ In his (The) Alienation of Reason Leszek Kolakowsky has extensively discussed this issue by thoroughly analyzing the developmental history of this process of reduction and its societal implications. See Leszek Kolakowsky, 1966. TheAlienation of Reason (trans. by N. Guterman), NewYork: Doubleday \& Company, 1968. See particularly Chapters Four and Five. pp. 73-133. 


\section{Philosophy International Journal}

instrumental reciprocation with power-oriented disciplines and institutions made possible the attainment of the aim of the social sciences' self-determined status as 'science' Thus, the 'epistemological infrastructure' of the 'project of Enlightenment' whose horizon is. 'Societal rationalization' was determined by this type of rationalism that dominated the modern world of the social. Here, in this context of Enlightenment, the hidden paradox of modernity is revealed: although this perception of rationality and societal rationalization is fundamentally opposed to the Enlightenment's rational ideal of liberty, this type of rationality has come to dominate the modern world of the social. By its (techno-) 'scientific' and technocratic achievements in the powerinterest realm of social undertakings, this facet of modernity has exclusively become the 'genuine' image of Enlightenment by an instrumental type of societal rationalization. Analyzing the developmental history of this paradox, Foucault proposed a critical description regarding the origins of modern totality by unveiling its 'monument of reason'. This totality is entrenched in the (predominantly positivistic) pre-conditioned rudiments of the modern concept of knowledge. Therefore, as described by Foucault, the 'human sciences'

...are not sciences at all; the configuration that defines their positivity and give them their roots in the modern episteme at the same time makes it impossible for them to be sciences; and if it is then asked why they assumed that title, it is sufficient to recall that it pertains to the archaeological definition of their roots that they summon and receive the transference of models borrowed from the sciences. ${ }^{17}$

This view of things regarding the 'human' and the 'science' reflects the problematizing of the Enlightenment as societal rationalization by exposing the critical elements underlying the philosophical discourse on modernity. Thus, in restating the concept of Enlightenment as ranging between the edges of the 'horizon of hope' and 'anatomy of despair', human reason outlines progress as a moral entity which ought to come first and foremost. In dealing with the social significance of modernity, we consider the moral meaning of the concept of progress, which in large part claims the Enlightenment as an ethos to be a matter of debate leading to the question: Does progress spell a horizon of hope ran anatomy of despair?

Our consciousness as (modern) human beings in both aspects of 'nature' and the 'social' is informed by our

\footnotetext{
17 See Foucault, The Order of Things. P. 366. Seealson. 11 above.
}

perceptions about 'reason', 'rationality', 'knowledge', 'understanding', and basic assumptions about 'human nature'. This would probably be pertinent regarding an imagined concept such as the 'modern mind' where 'knowledge' as a rational reflection of reason involves human interests. The triumph of the modern concept of scientific knowledge or the scientific method has made a decisive contribution towards the formatting 'paradigm' of societal rationalization by the dominance of positivism ${ }^{18}$. This trend which may, inter alia, be characterized by scientism, touches upon a determination of a consciousness of modernity. However, the point is that in part it influences the formation of the individual's life and the 'self-determination' of sociopolitical structures, praxis and culture. As a central feature of modernity and modernization, societal rationalization which is life world generating - plays a crucial role in shaping the modern world of the social.

This feature of societal rationalization encompasses both the individual and society and the consequences of their interaction. The concept of (modern) 'society' is about both its levels of reference -'community' and 'political community'. First and foremost, it embraces the moral foundations of social structuration and the reconstructing dynamism of institutions of liberty. It is about the moral value sphere within which social and political processes of legitimation are anchored, or upon which these processes should be constituted. In other words 'modernity', as both an ethos and the articulating characteristic of a particular social reality is interwoven in the formation of what might be called a 'consciousness of modern life world'.

Conceived within the context of societal rationalization, 'modernity' is an ethos of a moral significance. Behind this relationship at the core of the philosophical-critical discussion of modernity lies the perception that views of 'society', 'community'/'political community' and 'life world' as moral entities come first and for most. The morality of freedom and all its implications are subsumed under the notion of 'right(s)'. In considering forms of rationality and societal rationalization through the prism of a moral dimension, the socio cultural inferences of 'knowledge' are at the core of the philosophical-critical discourse on modernity. 'Knowledge' in its disciplinary form in particular (as this is one of the defining characteristics of modernity) is not only a source of power but also a formatting factor in the

\footnotetext{
${ }^{18}$ Described by Leszek Kolakowski as "Positivism Triumphant," which is the title of Chapter Four of his book, TheAlienation of Reason, New York: Doubleday, 1968. Pp. 71-103.
} 
structuration of the modern world of the social. Moreover, unlike the world of the social, 'nature' as an 'investigative object' is indifferent to any scientific procedure of theorization or law. In the world of the social, no 'given laws', 'scientific facts' or 'scientific theory' 19 of significance is possible. The human and the social as an 'investigative object' may by no means be acknowledged as indifferent as nature is. This is so because 'the social'- culture, community, institutional structures, morals, polity, legislative bodies-is an artifact, meaning it is manmade, using reason, given that the issue at hand is the modern perception of man and society. Hence, since 'open society', which epitomizes liberty as a normative guideline (contrary to 'providence' or 'natural evolutionism' or determinist conception, or any pre-given destiny or vocation),the legitimacy of social order and polity is, or should be, rationally anchored. That is to say, as an artifact of human reason (or the 'public use of reason'), sociopolitical arrangements are subject to a dynamic reconstructive criticism. If the natural right of liberty is a conditioning element for other rights (and the rights of others), then freedom of speech and opinion must be paramount. Foucault's understanding of parrhesia manifests this premise reconstructively by anchoring it in a self-perception of mankind, a psycho-conscious autonomous entity.

\section{Parrhesia -Truth by Courageous Discourse}

The most immediate connotation of the term 'Enlightenment' brings to mind the intellectual movement that spawned ideas in a variety of disciplines - in both the sciences and the humanities - out of which sprang the basic outline of modernity. However, a specific focus on the social aspects in this context is a necessary condition for the essential understanding of the term's historical meaning for the comprehensive entity of the 'modern state' and the ethos of 'modernity'. The ambition to bring about the rational scientific method that became the foundation of a new concept of order puts the Enlightenment as a decisive intellectual force for revolutionary change at the core of the modern

\footnotetext{
${ }^{19}$ In dealing with the concept of 'science' in view of its epistemological aspects (which, inter alia, distinguishes between 'science' and 'non-science' or 'pseudo-science') Karl Popper observes, "Science is not a system of certain, or well-established, statements; nor is it a system which steadily advances towards a state of finality. Our science is not knowledge (epistēmē): it can never claim to have attained truth, or even a substitute for it, such as probability [...] Although it can attain neither truth nor probability, the striving for knowledge and the search for truth are still the strongest motives of scientific discovery." See Karl R. Popper, 1968. The Logic of Scientific Discovery, London: Hutchinson, 1959. P. 278.
}

Oram M. The Changing Ethos of the Enlightenment in Foucault's Discourse on Parrhesia. Philos Int J 2018, 1(1): 000106. perception of sovereignty and political regime. Posing the question - "What is it in the present that now makes sense for philosophical reflection?" 20 - Foucault has actually emphasized the Enlightenment's vocational meaning of philosophy and therefore the philosopher's vocation as critical discourse. That is, philosophical contemplation in its Socratic spirit - the critical use of reason - carries with it a moral obligation and responsibility toward the moral quality of communal existence within which man, (every individual)as an autonomous and free personality, is part of the transformation of the abstract 'we 'to an actual 'us':

No philosopher can go without examining his own participation in this us precisely because it is this us which is becoming the object of the philosopher's own reflection. All this, philosophy as the problematization of an actuality and the philosopher's questioning of this actuality to which he belongs and in relation to which he has to position himself, may very well characterize philosophy as a discourse of and about modernity 21 .

That is, philosophy (and thus the philosopher) has no significance and value in itself, but rather in the objective moral-critical orientations it carries towards its humansocial environment. The philosopher's place in a particular reality and life world is articulated through the commentator's commitment to criticizing this social existence by virtue of being a citizen and a member of a community. This is the "politics of truth," which is preconditioned on active citizenship; at its center Foucault has placed the challenge of clarifying the actual meaning of the Enlightenment and progress. From this perspective, in his philosophical investigation he examines three dimensions of philosophical inquiry in the broad context of man's existence: the 'relation to the present', the 'historical mode of being' and the 'autonomy of the self'22. The philosopher's active commitment to the 'present reality' as its commentator forms the basis for understanding the modern meaning of critical thought through the classical concept of parrhesia.

\section{I.}

One may imagine 'modernity' as an era characterized by the multifaceted ability to create and reproduce 'manipulated truths'. 'Truth' may be received as a 'fact' or 'indisputable reality', though from different ways of consideration according to a different consciousness,

\footnotetext{
${ }^{20}$ Michel Foucault, 1980. "What is Revolution?" in The Politics of

Truth (edited by S. Lotringer and trans. by L. Hochroth and C.

Porter), Los Angeles: Semiotext(e), 1997. P. 84.

21 Ibid. P. 85.

${ }^{22}$ Ibid. P. 109.
} 


\section{Philosophy International Journal}

cognitions, life worlds and fields of knowledge. This variety may be expressed differently in the world of natural phenomena, in any 'empirical corroboration', in the substantiation of 'rational truth' or in the world of the social. For the scientist 'scientific truth' is a solid truth no less than divine revelation is for the believer. But the difference is that the former can always be rooted in the existence of the clear and open possibility for falsification, which of course is impossible with religious belief, not to mention the lack of any means of verification. Any 'indisputable fact', however, may at some point in time and/or place be revealed as a mistake, a sophisticated manipulation, a deliberate falsehood or deception. It is therefore clear, for example, that 'scientific truth' is unlike 'historical truth' and so accordingly is the authority and power of these different categories of truth. The same can be said about the manipulative power of reason, which is reflected in the diametrically different procedures of verification and falsification in the two distinct worlds of the phenomena - 'nature' as opposed to the 'humansocial.' That is, in the world of nature truths are revealed, while in the social they are man-made. Thus, it might be said that the more falsification there is, the more it becomes (in one way or another) clear and overt, while it is far more difficult to construct or manipulate 'scientific truths', because scientific theories apply to the physical world and as such are much more solid and stable. 'Paradigm shifts' and 'revolutions' are more frequent in the world of the social and at least in this respect these in no way are comparable to scientific revolutions. Wherever scientific categories of thinking dominate the human-social world and humankind becomes a 'scientific subject' stripped of its moral autonomy (its personality), this is merely the embodiment of another facet of totalitarianism. Moreover, the seal of 'science' is not necessarily a guarantee, and such falsity is no less dangerous than religious fanaticism.

Skeptical thinking and exploration are at the heart of progress. Therefore, one is obliged to ask questions about 'truth': What is the (social) grounding in which truth grows? What does the public use of reason comprise that should justify maintaining it? How would such reason cultivate the tendency to totality? Invoking parrhesia, Foucault illuminates 'the how' and 'the where' we are duty-bound to disclose manipulated truths for the falsehoods they are by employing publicly expressed, skeptical thought processes and thereby fearlessly challenging that which is cast as 'real' just because it is commonly acknowledged as 'actual' accepted truth.
'Truth' for Nietzsche is a sort of a 'conventional distortion', an agreed lie or self-deception ${ }^{23}$. Based on Nietzsche's criticism of Kant, it seems that this critical idea of 'truth' may be revealed as a sort of lie directed at the commonality of 'publicly held' or 'widely acknowledged' truths. To interpret it in accordance with Foucault's criticism of the Kantian perception of Enlightenment, this revelation would occur when the public use of reason "[...] will be the best guarantee of obedience [...]." ${ }^{24}$ Therefore, parrhesia is, first and foremost, a moral, active entity open to public consideration of 'truths', thus the 'temporariness' of 'certain truths' is declaratively revealed. Likewise, the alteration of the political imagination is generated by free individuals to undermine manipulated truths, which are a constituent of the infrastructure underlying 'indisputable reality.' This type of 'reality' renders a solid basis for various forms of totalitarianism.
${ }^{23}$ For example, see The Gay Science (1882), wherein Nietzsche describes the "Sense of truth.-- I think well of all skepticism to which I may reply: 'Let us try it.' But I no longer want to hear anything of all those things and questions which do not permit experiments. This is the limit of my 'sense of truth': for there courage has lost its rights." Friedrich Nietzsche, The Gay Science, in Basic Writings of Nietzsche (trans. and ed. by Walter Kaufman), New York: The Modern Library, 1968. P. 171. Also, “...certainty is what drives one insane. But one must be profound, an abyss, a philosopher to feel that way. We are all afraid of truth." Friedrich Nietzsche, Ecce Homo, in Kaufman, ibid. P. 702. For Nietzsche's discussion of the 'will to truth,' see Friedrich Nietzsche, "On the Prejudices of Philosophers," in Beyond Good and Evil: Prelude to a Philosophy of the Future(trans. by J. Norman), Cambridge: Cambridge University Press, 2002. Pp. 5-24.

${ }^{24}$ Foucault, "What is Enlightenment?" in The Politics of Truth. P. 103. Foucault's criticism of Kant's perception of the Enlightenment in this context rests on the latter's conception of freedom which is, according to Foucault, all the same since the sixteenth century, where freedom of consciousness was reductively determined as the 'right to think' as long as one obeys. Herein Kant makes a surprising distinction, says Foucault, by differentiating 'private' and 'public' uses of reason: 'public use of reason' must be free, while in its private use it must be submissive. This is the very opposite of freedom of consciousness, says Foucault. Consequently, the individual in his 'private use of reason' is but a particular segment of society - as a taxpayer, soldier, civil servant, etc., like a "cog in a machine" (Foucault's description). This may by no means be conceived as the free expression of reason because it is subjected to predetermined ends. The expression of reason will be free and public only when one articulates reason autonomously as a reasonable being, as part of reasonable humanity. Therefore, Foucault's conclusion is that "Enlightenment is [...] not merely the process by which individuals would see their own personal freedom of thought guaranteed. There is Enlightenment when the universal, the free, and the public uses of reason are superimposed on one another." pp. 102-103. 
Parrhesia ${ }^{25}$ may be imagined as having a basic affinity with the 'public interest' or the 'public domain', which in a simplistic formulation may be supposed as anything outside the realm of privacy. However, as Foucault points out, the ordinary definition of parrhesia is 'free speech.' And in the modern practical and conceptual usage, the realm for such untainted, honest expression is the 'public sphere.' Yet, in the wider context of 'modernity' 26 particularly in view of the increasing complexity of the modern world of the social - one should not presume as taken for granted the authenticity of a genuine public interest in the distinct realm of the public domain.

Moreover, this authenticity can hardly be found even in the representative institutions of modern liberal democracy. However, in any reference to the 'public sphere' as a distinctive dimension in the entire complex of the 'public domain', some questions may immediately arise: Who is the public? How should this sphere be demarcated? What is the source of authority? By whose power? Whose legitimacy? In the reality of a centralized power that is oriented to the appropriation of public interests and properties in a vast flood of information, knowledge, communication and media, the 'public sphere' seems to be much more like the arena where manipulated truths are shaped, namely, in the virtual terrain for a biased collective memory that has become the realm where public opinion and interests are pre-ordained. Therefore, in the use of the classic term of parrhesia, Foucault deals with the essence and necessity for an open public discourse and free speech, which is a prime and primary condition for a free and open society that must be defended ${ }^{27}$.

\footnotetext{
${ }^{25}$ For a detailed discussion of the term, see Michel Foucault, 19831984. Fearless Speech (edit. by J. Pearson), Los Angeles: Semiotext(e), 2001.It seems to me that it should be noted that Foucault draws our attention to the French translation, which is franc-parler-'open' and 'direct' speech. Parrhesia as ordinarily translated into English, says Foucault, as "free speech." pp: 11.
}

\footnotetext{
${ }^{26}$ Foucault explicitly rejects the concept of "postmodernity," which is "enigmatic and troubling" ("What is Enlightenment?" in The Politics of Truth. P. 105). This rejection stems from his perception of 'modernity' as an attitude, which is "...a mode of relating to contemporary reality." Ibid. We are supposed to perceive modernity as in the Greek meaning of ethos, says Foucault, not as a period of history; therefore, "rather than seeking to distinguish the 'modern era' from the 'pre-modern' or 'postmodern,' I think it would be more useful to try to find out how the attitude of modernity, ever since its formation, has found itself struggling with attitudes of 'countermodernity'." Ibid.

${ }^{27}$ In a series of lectures (Collège de France, 1975-1976) gathered in a volume entitled Il faut défendre la société (Society Must Be Defended), Foucault discussed the 'social entity' by way of a philosophical analysis and historical-political survey of power relations and political sovereignty. See Michel Foucault, 1975-1976. Il faut défendre la société - Cours au College de France, Paris:
}

\section{II.}

'Politics of truth' and parrhesia are both a condition and a means to 'defend the society.' In Fearless Speech, ${ }^{28}$ Foucault specifically discussed the state of democratic institutions in the critical context of the public sphere and defense of the self through the prism of a Socratic deliberation of parrhesia. Discussing the social implications of the word, as its etymology demands, through the 'connotative framework' of 'frankness', 'truth', 'danger', 'criticism' and 'duty', Foucault illuminates the moral weight of parrhesia as an idea.

Etymologically, the basic meaning of the word parrhesia, as Foucault interprets it is 'frankness', which points to parrhesiazesthai, meaning "to say everything" that is on one's mind, viz., one's opinions or beliefs. However, the franc-parler, or open and direct speech, carries a risk because the parrhesiastes (the one who uses parrhesi ${ }^{29}$ ) may say something that endangers himself.

As parrhesia is 'truth' and 'courage' intertwined, it is clear that without both 'truth' and 'courage', neither genuine criticism nor critical thought can occur. Such criticism will rarely be sympathetic, neither in interpersonal relationships nor especially in the political context where the one denounced is the sovereign; and this is particularly true in the totalitarian, authoritarian political reality. In general, the specific value of any critical remarks or judgments lies in its suggested reconstructive potential vis-à-vis the subject of the criticism. That is, parrhesia as a "game" between the speaker of truth and an interlocutor, ${ }^{30}$ involves advice to take action or not, or to adopt a different policy or behavior or not. As may be understood intuitively, criticism that intrinsically includes a constructive dimension has a better chance of success before a "cornered" interlocutor. Then, parrhesia is not merely

\footnotetext{
Gallimard, 1997. For the English translation, see Michel Foucault, 2003.Society Must Be Defended - Lectures at the College de France 1975-76(trans. by D. Mecy), New York: Picador. See lectures 2, 3, 8 and the Course Summary.

${ }^{28}$ See Foucault, Fearless Speech. Pp. 77-133. For the ancient and modern meaning of the Greek concept of parrhesia as discussed by Foucault through 'frankness,' 'truth,' 'danger,' 'criticism' and 'duty', see Pp. 11-20. This perception of parrhesia, especially 'criticism' and 'duty', is that which connects it to Foucault's understanding of the Enlightenment.

${ }^{29} \mathrm{He}$ “...who says everything he has in mind [...] opens his heart and mind completely to other people through his discourse." Fearless Speech. P.12.

30Ibid. Pp. 17.
} 


\section{Philosophy International Journal}

'fearless speech', 'truthfulness' and 'frankness'; it is a form of criticism ${ }^{31}$.

At all events, though the ancient Greek world is context-specific to our discussion so far, an important question arises: Why would a person decide to be a parrhesiastes? Why take the risk? Why endanger one's life, good name and reputation? Why jeopardize the privilege of free speech by disclosing a truth that threatens the majority? Athenian leaders, Foucault reminds us, "...were exiled only because they proposed something which was opposed by the majority...." Therefore, he adds, the assembly was "protected" against the truth"32. How then should we consider the man Socrates - on the one hand, the most famous parrhesiastes in the Apology, and on the other, the philosopher who submissively accepts death by hemlock poisoning in Crito. Is the 'truth' something worth dying for? And so we encounter the last characteristic of parrhesia introduced by Foucault - 'duty'.

Here, Foucault clarifies the meaning of the 'parrhesiastic act' as it relates to 'freedom' and 'duty'. A purely voluntary (not enforced by a court) confession of misdeeds (a crime, for example) may be considered a 'parrhesiastic act'. Similarly, criticism will be deemed a parrhesiastic act insofar as it stems from a genuine commitment to help by improving something or fixing it. Criticizing the king with the aim of helping him to better himself as a sovereign is the duty of a citizen of the city ${ }^{33}$. The same holds true for a friend who is unaware of his wrongdoing; it is a duty to criticize him with the intention of helping by giving sage advice, etc. Both are parrhesiastic acts. In Socrates' case, it may be said that being a parrhesiastes is among the philosopher's duties at both relational levels - between the citizen and the citystate and on the interpersonal level. That is, unlike the orator, the philosopher does not have the 'privilege' to keep silent. Foucault concludes this discussion on the

\footnotetext{
${ }^{31}$ In this context in which Foucault refers to the Athenian-Greek sociopolitical culture, he notes that the use of parrhesia was not open to everyone. The parrhesiastes, says Foucault, was supposed to know his own genealogy whereby his status was defined. The right to be enrolled in this circle of the entitled was granted only to a male citizen. Anyone deprived of parrhesia was considered of equal status to a slave with no right to participate in political life (métoikoi). Those privileged to speak before the assembly (ekklesia) had to be male citizens who possessed specific personal, moral and social qualities. This was democratic parrhesia. In light of this institutional background of "democratic parrhesia," Foucault stresses the significance of distinguishing "democratic parrhesia" from the monarchic variety "... where an advisor gives the sovereign honest and helpful advice." Fearless Speech. P. 19.

${ }^{32}$ Ibid. P. 18.

${ }^{33}$ Ibid. P. 19.
}

characteristics of parrhesia, by stating its inherent moral dimension:

[...] parrhesia is a verbal activity in which a speaker expresses his personal relationship to truth, and risks his life because he recognizes truth-telling as a duty to improve or help other people (as well as himself). In parrhesia, the speaker uses his freedom and chooses frankness instead of persuasion, truth instead of falsehood or silence, the risk of death instead of life and security, criticism instead of flattery, and moral duty instead of self-interest and moral apathy. That then, quite generally, is the positive meaning of the word parrhesia in most of the Greek texts where it occurs from the Fifth Century B.C. to the Fifth Century A.D ${ }^{34}$.

\section{III.}

The 'crisis of modernity' may (partly) be visualized through the crisis of democratic institutions. ${ }^{35}$ In a modern (mass society) democracy, a major facet of this crisis of democratic institutions is the growing gap between the state's power together with other powerful institutions and the public. However, the fundamental elements involved in this problematic and, as we have reviewed, these issues as they apply to the modern world of the social were addressed in Plato's writings. Socrates as he appears in Plato's writings, particularly in the Apology and Crito, as the protagonist in these parrhesiastic dramas - is a courageous personality who is prepared to die for his truth, which is a penetrating criticism of the Athenian lifeworld. Socrates, the parrhesiastes, is revealed either in a blunt confrontation against Anytus and Meletus, the prosecutors who sentenced him to death, or as reflected in his 'irritating talks' with passersby in an Athenian street. This prominent parrhesiastic persona of Socrates reflects the essential and necessary link between caring about oneself and about one's civic duties as a citizen. This concern for the 'good polis' translates into how people ought to strive to live a life worth living. The concept of a 'proper life' is thus intertwined with one's active engagement in the shared responsibility for the welfare of the community, which is at the heart of being a citizen. This is the moral basis of politics. However, if the crisis in democratic institutions that are being constantly undermined by the loss of their moral foundations continues to its logical conclusion, then immorality and ignorance will lead to tyranny.

\footnotetext{
${ }^{34}$ Ibid. P. 19-20.

35"Parrhesia in the Crisis of Democratic Institutions" is the title of Foucault's 'fourth lecture' (November 14, 1983), which he delivered at the University of California at Berkeley in the fall term of 1983. See Fearless Speech. Pp: 77-87.
} 


\section{Philosophy International Journal}

In Foucault's problematization of parrhesia we can recognize the analytical outlines regarding the relationship between 'thought' and 'reality'. In this particular reading of parrhesia, as interwoven with the significance and weight of the concept of 'truth', we may identify the roots of a specific philosophical discourse on modernity, whereas its moral core is the 'hermeneutic perspective' of the self.

Dealing with the relation between 'language' and 'knowledge', Foucault notes a general phenomenon whose beginning is attributed to the seventeenth century. As described in The Order of Things, it is the withdrawal of language to a transparency and neutrality that, following Descartes, ${ }^{36}$ the written word has ceased to be included among the signs and representations of truth. That is, by a certain rational denotation of thinking, the concept of 'truth' was acquiring an affinity with the scientific method; 'truth', like 'knowledge', is an evident and distinct perception. Studying the 'genealogy of the subject' at the level of the history of science, Foucault illuminates the interrelations between 'knowledge' and the 'self' through the practices that define and transform 'the subject'. Moreover, dealing with the Western context of modern culture, these practices are accompanied by the formation of certain types of knowledge, which more or less is based on a scientific pattern, or at least is targeted as such. Precisely in this context of modernity, we should distinguish the moral meanings and implications of 'knowledge' and 'knowing' as a facet in the context of truth. 'Knowing oneself', telling the truth about oneself and being constituted as an object of knowledge, says Foucault (may be in a Socratic spirit of gnothi seauton("know yourself")), is one of the main moral obligations for everyone. Then, in this context of modernity, 'knowledge' which, articulated in its scientific normativity, is as formative as a paradigm for 'truth' by 'institutions of knowledge' that obtain the power to manipulate it.

The 'genealogy of the subject' is, therefore, a wideranging search for the genuineness of the self. And through the prisms of developmental history of knowledge, Foucault exposes one of the most important foci of critical thought in the philosophical discourse on modernity - the problematic of the 'scientific knowledge' of the self. Among the consequences of this search, he notes that his work on the history of science aims at revealing what gave rise to these sciences, which sought to construct a scientific knowledge of the individual subject. Moreover, in dealing with this problematic from

\footnotetext{
${ }^{36}$ Foucault, The Order of Things. Pp: 56.
}

the aspects of psycho-social practices, institutions and discourse, Foucault transforms the discussion into a political one. Using the method of the 'archaeology of knowledge', he aims toward the construction of a 'genealogy of the subject'. This challenge consists of three interrelated investigational reference points: a. the time when these social practices became techniques with definite goals; b. the way these techniques came to be seen as true; and c. the point at which we may indicate a linkage between these techniques and the obligation to search for the truth and to tell the truth. Consequently, in the questions that arise from this challenge lie the political meaning of this theoretical analysis that paves the way for another, idiosyncratic kind of critical philosophy.

'Politics', in a minimal and generalized definition, may be described as the dimension of human activity where values are being transformed into obligatory norms that effect the life of a certain community of people. In the classical meaning of praxis, it is a distinct complex of active decisions (as in war or athletic games) in the community's life and future. 'Politics' in its modern designation of Western liberal democracy is the sphere where free people participate (through their representatives) in these decisions and the legislation that govern their lives. In the modern existential experience regarding aspects of the individual's autonomy, critical philosophy is supposed to seek out the possibilities for change and transformation. Whereas 'modernity's discontent' is related to the oppressive potentialities of disciplinary knowledge and the state's administrative authority, as a result of which the autonomy of the individual is suppressed, it is at this point that critical philosophy and politics become interwoven through this dimension of the care of the self. That is why Foucault articulates his project by taking up the challenge to search for another kind of critical philosophy. Thus, in order to determine new directions, it is an 'active' critical philosophy that will outline the way for the possibilities and conditions of an autonomous individual ('subject') for the transformation of the self.

From the essential features of his work, we can see the prominence of Foucault's analysis of the human based on the challenge of studying the perception of the individual and his treatment in different institutional frameworks like the hospital, the asylum and the prison, as gleaned from practices and techniques of control through deprivation of liberty. Foucault deals with these practices of control while revealing the processes of reducing certain individuals (or 'subjects') to objects of knowledge. 
Introducing a kind of auto-critique, ${ }^{37}$ Foucault points out three major types of technique in human societies as suggested by Habermas. ${ }^{38}$ These are the main ways human societies allow one to produce, transform and manipulate things as sign systems; but above all, the ways or techniques of determining the behavior of individuals. As introduced by Foucault, at issue are the techniques of 'production', 'signification' and 'domination'.

Similarto the problematic of truth-telling and the practice of parrhesia in community life, the 'technology of the self' is framed by ancient philosophy as Foucault deals with it from the Delphic precept of gnothi seauton. In the broad context of the modern world of the social in Western civilization, the analysis of the 'genealogy of the subject' is connected to the techniques of the self that interact with the techniques of domination. That is, a notable characteristic of modernity is those points where the techniques of the self are integrated into structures of coercion and domination. Consequently, 'critical philosophy' will be seen as lacking, as an impoverished concept without a frank and open exposure of these points. This means those 'hidden truths' whose exposure by means of parrhesiastic acts is rudimentary as a precondition for extracting the democratic institutions from their crisis, which is but one indicative dimension of the interrelations between 'modernity and crisis'.

Next, the concept of 'truth' should not be reductively formulated; it should not be narrowed to the meaning of 'my truth', 'my-self' in relation to others or as interrelated with others or something outside 'me'. In this respect, let us say that Foucault acknowledges Rousseau's psychosocial insight of amour de soi and amour proper, but not as differentiated types of consciousness. In Foucault's critical philosophy these two dimensions of conciseness are molded into the integrating conception of the 'care of the self', whereas the dimension of amour de soi is implicitly at its core a formulating prism for a critical analysis of the 'modern condition'. In other words, the individual subject (the 'human condition'), which is mainly articulated by disciplinary knowledge, should be the moral touchstone in any socio-political ordering and institutions. ${ }^{39}$

\footnotetext{
${ }^{37}$ Foucault notes this specifically in his trilogy of The History of Sexuality: The Care of the Self, trans. by Robert Hurley, New York: Random House, 1986; see also Foucault, The Politics of Truth. Pp. 153 and 166 , note 5 .

${ }^{38}$ See Jürgen Habermas, 1968. Knowledge and Human Interest, London: Heineman, 1972.

${ }^{39}$ At this point a noticeable difference between Foucault and Habermas must be noted. While for Foucault the individual, the self, is a moral criterion of the 'modern condition,' for Habermas it is 'communal solidarity,' the societal elements of consent and integration. This yields, accordingly, different challenges in each of
}

Therefore, the construction of a 'genealogy of the subject', as Foucault defined his project, is a wide-ranging search for the articulation of certain techniques and discourse about the subject. That is why in this project he attaches upmost importance to the truth concerning oneself as an autonomous entity.

Knowing oneself primarily indicates the determination of the self as the personal aspect in the comprehensive concept of 'self-determination', which is a constituent condition of liberty. The abstract ' $\mathrm{I}$ ' becomes (a real) 'me' whenever an 'individual' is a 'subject of rights' - a rights bearer. Therefore, 'otherness', either directed at any specific individual or at any human group, is an excluding articulation. It may be carried out by the power of religion, the 'scientific authority' of disciplinary knowledge or the differentiating force of nationality; in one way or another, it prepares the ground for the exclusion of individuals, and/or entire 'distinct' collectives from rights and liberties, as 'not entitled'. This excluding articulation, which is usually pronounced by those who hold the 'legitimate' majority's power or by an advantaged minority who hold specific, exclusive power (socio-political, economic or that of disciplinary knowledge) may serve as the legitimate basis for segregation and exclusion.

'Knowledge', 'truth', 'self-knowledge' and 'truth-telling' are the essential elements of self-determination. Foucault illuminates these dimensions of the self, beyond the 'narrow' sense of the individual's authenticity, as announcing one's autonomy. That is, individuality and liberty are integrated as one unified essence, not dependent on any institution of power. This distilled concept of liberty - which is in constant conflict or tension with the conditions of truth-telling - is a significant milestone in the socio-political history of modernity in the

\footnotetext{
these thoughts: for Habermas it is the bridge between critical thought, social theory and political praxis; whereas Foucault defined it as a "construction of a genealogy of the subject." This already explains the different nature of these two critical thoughts while they rest on a common denominator of critical assumptions regarding the 'rational problematic' as a connecting element between modernity and crisis. In this respect, Habermas' work may be characterized as searching for the modern lifeworld's contents toward a 'rational-communicative reconstruction.' Foucault's project, as a historian of thought, aims at a redefinition of critical philosophy through the study of the developmental history of knowledge and the crystallization of disciplines that constructed the modern institutions of power, and brought about a particular (modern) perception of the individual subject through the exercise of power. However, in light of the common ground of critical assumptions in the mentioned context of the 'rational problematic' one may find that beyond the opposing points at issue are two types of critical discourse of modernity that complement each other.
} 


\section{Philosophy International Journal}

context of crisis. And that at least may point to the direction we should search for in dealing with this problematic.

\section{Conclusion}

The basic assumption on which Foucault's critical thought rests symbolizes the changing ethos of Enlightenment. That is, 'modernity' and 'crisis' are intertwined through a rational (reductionist) articulating of the concept of 'reason'. In his critical discourse on modernity, which reflects the metaphoric image he himself gave to his philosophical investigations- an 'archaeology'- Foucault, the 'historian of thought' (as he called himself),exposes the origins of this crisis. It is about the dominance of a certain type of rationality (alienated to the Renaissance concept of 'knowledge') that established an oppressive concept of order within which more and more spheres of life are disciplined. Foucault's critical thought was examined here throught womomentous dimensions that his deliberation in this concern indicates a central axis in the multifaceted discourse demarcated in the topic of 'critical thought and modernity': a. the (modern) conception of 'reason', and b. the oppressive power of discipliner knowledge that has been formed into 'human science'. These two dimensions of critical thought merge into a prominent trend in his early monumental work - History of Madness (1961), and more specifically in his The Order of Things (1966), as well as his later work, The Archaeology of Knowledge (1969). The focused discussion in Foucault's sociopolitical criticism is the result of an in-depth comprehensive study of comparatively later writings and articles, most of which are lectures in the Collège de France and in the United States and Canada that he delivered in the late 1970s and the early 80s, a few years before his death in 1984. These were assembled in anthological volumes such as: Society Must Be Defended (1975-1976), The Politics of Truth (1978-1984), The Government of the Self (1982-1983)and Fearless Speech(1983).

The topics covered under the title of this article have been discussed in light of a central question resonating in his philosophical thought as a whole: Does Foucault's grasp of the epistemological premises of Enlightenment accord adequately with the concept of modern knowledge? To put it more precisely: Is the evolutionary history of the concept of modern knowledge, as Foucault presents it from the Renaissance to the Enlightenment, consistent with the characterization of the concept of knowledge that he delineates? Dealing with Foucault's consideration of the connection between 'modernity' and 'crisis' through the (modern) concept of knowledge, a precept made here indicates that this connection is an outcome of a transformation of the concept of 'reason' into rationality that its expression is the (positivist) human science(s). Specifically speaking, it is the connection between the modern concept of reason and totality.

From the critical perspective of Foucault's conception of the 'crisis of modernity', the question that arises is whether he should be identified with the so-called deconstruction trend or with the postmodern undermining trend which overwhelmingly rejects the Enlightenment. In this regard, the readings of Foucault as proposed in this paper demonstrate how labeling and classifications of this kind (any affiliation or association) merely impoverish the philosophical discourse on modernity. If modernity, as characterized by Foucault, represents the 'project of Enlightenment', then its intrinsic totality by human reason is revealed. Therefore, 'societal rationalization' - the hallmark of modernity - is nothing but a deceptive process of support (with a semblance of legitimacy) to those institutions of power, control of mechanisms and supervision, and exclusion which constitute the modern concept of order.

To embody reason through one-dimensional (instrumental) rationality that dominate the processes of societal rationalization have a dual effect: the (a.) positivist perception of knowledge that underlies the 'discipliner knowledge' in the 'human sciences' yields the (b.) power of reproducing truths by this discipliner knowledge. It may be imagined metaphorically as the 'manipulative power of reason'. Thus, the problematization of the concept of 'truth' is indispensable in any deliberation of Foucault's philosophical-critical discourse on modernity. This is the context in which the concept of parrhesia is discussed here.

For Foucault the 'philosophy' and the 'philosopher' are bound together by their very nature. Striving to revive the classic role of the auditor-philosopher as the criticizer of reality-social existence, he has uniquely revived the concept of parrhesia. In a series of lectures he delivered at the Collège de France and at UC Berkeley, California, one can find a thematic overview in issues that Foucault addressed earlier, such as 'truth', 'knowledge', the 'self' and 'polity'. In the last section (IV above) I extended the discussion of Foucault's critical philosophy by illuminating the interface between the classicalphilosophical world and Enlightenment ideas. 'The politics of truth' and the parrhesia are both the conditions and the means needed to defend society. As elucidated in this last section, Foucault specifically treats democratic 
institutions as the means of defense for the individual and society as viewed through the Socratic prism of parrhesia. In his examination of the social implications of this concept and in the broad context of 'truth', 'openly speaking', 'duty' and 'criticism', Foucault sheds light on the moral weight of parrhesia as an ideal.

Foucault's perception of the Enlightenment imposes a responsibility on the philosopher as a parrhesiastes - one who strives to advocate for truth by fearlessly and publically expressing his truth and one who dares to criticize and point up that which needs correcting. However, this alone is not sufficient: the philosopher must also ask himself "how I belong to a particular present" and not to a particular doctrine or tradition. This connection between the 'philosophy' (particularly as critical thought) and the 'philosopher' may explain why for Foucault 'postmodernity' is nothing but "enigmatic and troubling" (in his words). The starting point is that 'modernity' is not an epoch or a historical age which may narrowly be defined as differentiating between different eras - the 'modern' before vs. the 'postmodern' after. To the contrary, modernity is an ethos - a way of thinking, a sentiment and a consciousness; it is reflected in a certain human-social behavior and in a manner of activity. Consequently, instead of looking for demarcating definitions, Foucault seeks to evoke the questions that should be asked: whether or not 'modernity' (which is fulfilled through positivist scientism of the human-social world that generates a 'disciplinary violence') is a continuation and natural development of the Enlightenment? Or is a 'deviation' from the rational, moral and universal principles of the Enlightenment at issue? It is clear that any answer to these questions presupposes the possibility of knowing the essence of the Enlightenment, for Foucault casts doubt on Kant's answer to the question 'What is Enlightenment?' Therefore, we can accept his claim according to which, what is important is that we explain to ourselves how and why it happened that modernity is doomed to a constant struggle against anti-modern forces and trends. This is the critical significance of the philosophy itself, which is the essence of modern philosophy in the present context of our sense of reality. 